\title{
下斗米直昌 菊屬の人鴟俉數體に就らて
}

筆者は Chrysanthemum 屬の種々の “種”を用ひて種間交雜を行ひ，コルヒチンを用ひて種々 の異質倍數體を作つた。

作り得た 複二倍體は次の 11 種類である。japonense $\times$ indicum var. hexaploid, indicum var. hexa. $\times$ japonense, wakasaense $\times$ ornatum, indicum var. hexa. $\times$ ornatum, japonense $\times$ ornatum, shiwogiku $\times$ ornatum, ornatum $\times$ shiwogiku, japonense $\times$ pacificum, ornatum $\times$ pacificum, pacificum $\times$ ornatum, shiwogilu $\times$ pacificum. これ等の複二倍體はいづれも比較的 容易に生じ, 處理した株中多いときは $40 \%$ に達した。その外部形態は普通の複二倍體に於ける と同樣の特徵を具へ，減數分裂では多くは二價染色體のみが出現する。

上記の複二倍體を更に夫々他の “種”に交雜して次の 14 種類の三重雜種を作り得た。 ornatum $\times($ japonense $\times$ indicum var. hexaploid $)$, (japonense $\times$ indicum var. hexa. $) \times$ ornatum, shiwogiku $\times($ japonense $\times$ indicum var. hexa.), pacificum $\times($ waliasaense $\times$ ornatum $)$, (walasaensexornatum $) \times$ pacificum, $($ shiwogiku $\times$ ornatum $) \times$ indicum var. hexa., (shiwogiku $\times$ ornatum $) \times$ japonense, pacificum $\times($ japonense $\times$ indicum var. hexa.), (japonense $\times$ indicum var. hexa.) $\times$ pacificum, pacificum $\times($ indicum var. hexas. $\times$ ornatum $)$, (indicum var. hexa. $\times$ ornatum $) \times$ pacificum, (shiwogiku $\times$ pacificum $) \times$ ornatum, pacificum $\times($ shiwogiku $\times$ ornatum $)$, (shiwogiku $\times$ ornatum) $\times$ pacificum. これ等三重雜種は概ね生育力が强い。

上記の三重雜種をコルヒチンで處理してその染色體數を倍加せしめ複三重雜種を作ることを 試みた。處理した 841 個體中染色體が增加したと思はれるものが 103 株であつたが，染色體が 確實に二倍に霄加したものが單に 1 株見出されたの久であつた。此の 1 株は實驗した三重雜種 中染色體數の最わ少い組合せのもので, 其の正常の株では $2 n=90$ で，增加して $2 n=180$ とな つた。 $2 n=99,108,177$ を有する三重雜種に於ては, 多數の個體を用ひて實驗したにもからは らず逐に染色體が完全に二倍に增加したものが得られなかつた。これは恐らく本屬に於ては $2 n=180$ 以上では染色體數增加の極限に達してるて, 墰加が困難になる鹪と思はれる。

\section{增 井 清 鷄に於ける卵巢除去に依る實験的間性の研究 III. 白色レダホーン×シヤモ に於ける賽驗}

白色レグホーンメシャモの正逆交配の雜雜に於て 前研究と等しく畉巢除去の實驗を行ひ其の 性轉換の程度を觀察した。

性轉換度は第二次性徽に依らず前研究に於て 定めたや引に卵巢除去の結果として代償的に發 達する右側生殖腺の組織學的構造に依り强雌 (FF), 弱䧳 (Ff), 强䧳性間性 (IF), 弱雌性間性 (If), 中間性 (II), 弱雄性間性 (Im), 强雄性間性 (IM), 弱雄 (Mm), 强雄 (MM) の9 階級に分 類した。

日レグ゚メシャモ今 の雜種に於ける卵巢除去に依る性轉換の程度は雄性に 其の逆交配に於て は雌性に偏する傾向を示した。郎ち前者に於て總數 40 狗中雌性間性に屬するものは僅かに 2 牙

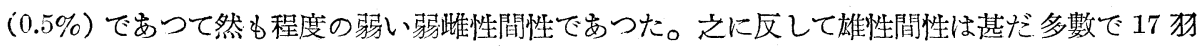
(42\%) に達し其の中 5 犲は强雄性間性であつた。後者に於ては總數 20 犲中 3 牙 $(1.5 \%)$ の雌 